\title{
Repression and Derepression of the Enzymes of the Pyrimidine Biosynthetic Pathway in Salmonella typhimurium
}

\author{
By JOHN M. SMITH, $\uparrow$ ROD A. KELLN \\ AND GERARD A. O'DONOVAN* \\ Department of Biochemistry and Biophysics, Texas A\&M University, \\ College Station, Texas 77843, U.S.A.
}

(Received 14 February 1980, revised 6 May 1980)

\begin{abstract}
Activities of five enzymes of the pyrimidine biosynthetic pathway and one enzyme involved in arginine synthesis were measured during batch culture of Salmonella typhimurium. Aspartate carbamoyltransferase, dihydroorotase, and the arginine pathway enzyme, ornithine carbamoyltransferase, remained constant during the growth cycle but showed a sharp decrease in activity after entering the stationary phase. Dihydroorotate dehydrogenase, orotate phosphoribosyltransferase and orotidine-5'-monophosphate (OMP) decarboxylase showed peaks of activity corresponding to the mid-point of the exponential phase of growth while remaining comparatively stable in the stationary phase. Derepression studies carried out by starving individual pyrimidine $\left(\mathrm{Pyr}^{-}\right)$deletion mutants for uracil showed that the extent of derepression obtained for aspartate carbamoyltransferase, dihydroorotase and dihydroorotate dehydrogenase depended on the location of the pyr gene mutation. Orotate phosphoribosyltransferase and OMP decarboxylase derepression levels were independent of the location of the pyr mutation. Aspartate carbamoyltransferase showed the greatest degree of derepression of the six enzymes studied, with pyrA strains (blocked in the first step of the pathway) showing about twice as much derepression as $p y r F$ strains (blocked in the sixth step of the pathway). A study of the kinetics of repression on derepressed levels of the pyrimidine enzymes produced data that were compatible with dilution of specific activity by cell division when repressive amounts of uracil were added to the derepression medium.
\end{abstract}

\section{INTRODUCTION}

The present work was undertaken to provide a reference study on the repression and derepression levels of the enzymes of a general biosynthetic pathway in bacteria. Because of our previous experience with the pathway and because of the availability of the appropriate strains, we chose the pyrimidine biosynthetic pathway in Salmonella typhimurium (Fig. 1).

The first step was to investigate the derepression levels possible in mutants with known deletions in their pyrimidine structural genes ( $p y r)$ under conditions of limiting uracil. Before a valid comparison could be made, the enzyme activities of the wild-type $S$. typhimurium, strain LT2, under identical conditions, had to be determined. Previously, it has generally been assumed that the enzyme activities of cells in the exponential phase of growth are constant with respect to specific activity (Bellino, 1973). However, in order to validate this assumption, we conducted experiments to determine if the enzyme levels, when ex-

$\dagger$ Present address: Department of Cellular, Molecular and Developmental Biology, Oklahoma State University, Stillwater, Oklahoma 74078, U.S.A.

$\ddagger$ Present address: Department of Chemistry, University of Regina, Regina, Saskatchewan, Canada S4S 0A2. 


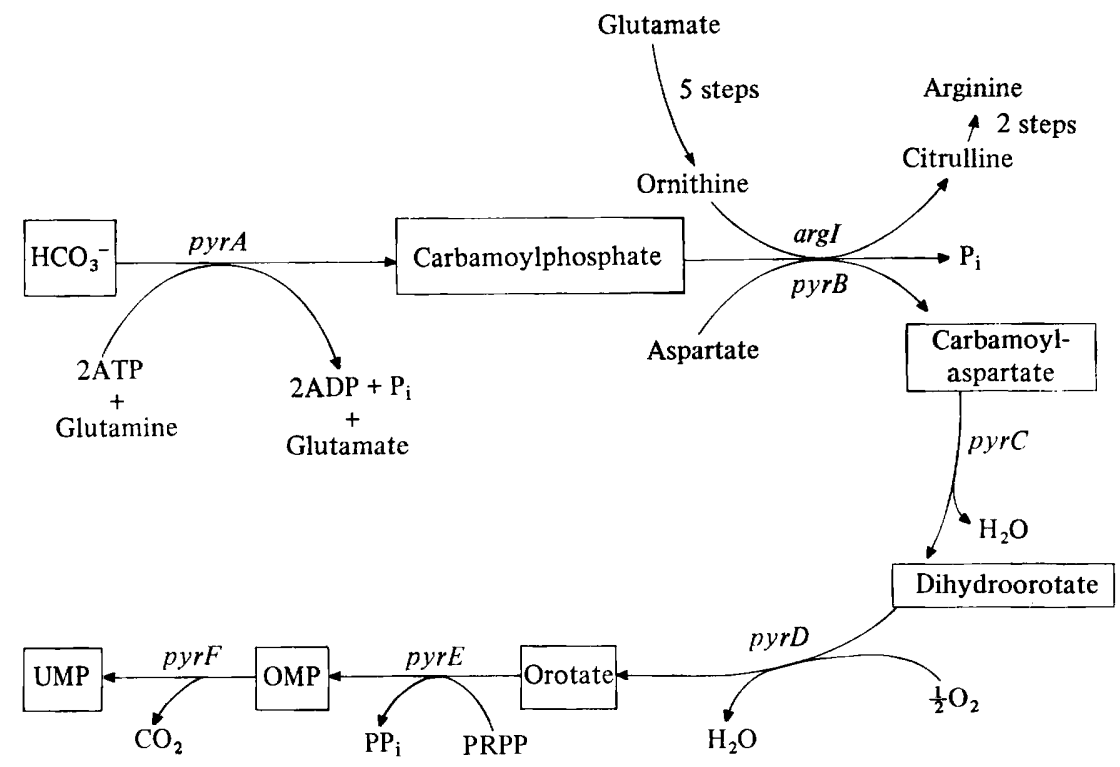

Fig. 1. Pyrimidine and arginine biosynthetic pathways in Salmonella typhimurium. The gene designations are as follows: $p y r A$, carbamoylphosphate synthetase (glutamine hydrolysing); pyrB, aspartate carbamoyltransferase; $p y r C$, dihydroorotase; $p y r D$, dihydroorotate dehydrogenase; $p y r E$, orotate phosphoribosyltransferase; $p y r F$, orotidine-5'-monophosphate (OMP) decarboxylase; argI, ornithine carbamoyltransferase.

pressed as specific activities, did remain constant during the growth cycle of the batch culture. Determining the enzyme activities during various phases of the growth cycle was important for the choice of the sampling points where cells were harvested: we wished to work within a constant range where the enzyme activities appeared highest.

After these preliminary studies were concluded, the pyrimidine enzyme activities of various Pyr $^{-}$deletion mutants were assayed under conditions of limiting uracil. The logical next question appeared to be how the cell would adjust such derepressed levels of enzyme if sufficient quantities of uracil were made available. Two possibilities seemed to exist: would the cell achieve repression by enzyme turnover or would a dilution effect occur in which the activity of the particular enzyme was halved with cell division? The repression kinetics were studied to determine which possibility applied.

\section{METHODS}

Organisms. All bacteria used in this study were derivatives of $S$. typhimurium LT2 (Table 1). Stock cultures were maintained at $4{ }^{\circ} \mathrm{C}$ on nutrient agar slants, supplemented as required with the appropriate compound.

Growth media. Bacteria were grown in TF (Munch-Petersen \& Neuhard, 1964) liquid medium containing the following components ( $\mathrm{g} \mathrm{l}^{-1}$ in distilled water): Tris, $12 \cdot 0 ; \mathrm{KCl}, 2 \cdot 0 ; \mathrm{NH}_{4} \mathrm{Cl}, 2 \cdot 0 ; \mathrm{MgCl}_{2} \cdot 6 \mathrm{H}_{2} \mathrm{O}, 0 \cdot 5$; $\mathrm{Na}_{2} \mathrm{HPO}_{4} \cdot 2 \mathrm{H}_{2} \mathrm{O}, 0 \cdot 178 ; \mathrm{Na}_{2} \mathrm{SO}_{4}, 0.05 ; \mathrm{D}$-glucose, $2 \cdot 0$. After the $\mathrm{pH}$ had been adjusted to $7 \cdot 7,1 \cdot 0 \mathrm{ml} \mathrm{FeCl}$ solution $(10 \mathrm{~mm}) \mathrm{l}^{-1}$ and $5 \mathrm{mg}$ anhydrous $\mathrm{ZnSO}_{4} \mathrm{l}^{-1}$ were added. Pyrimidines and amino acids were added to the basal medium in various concentrations from 0 to $50 \mu \mathrm{g} \mathrm{ml}^{-1}$ according to the dictates of each individual experiment. Solid medium was made by adding $20.0 \mathrm{~g}$ agar (Difco) $\mathrm{l}^{-1}$ to the basal medium.

Growth conditions. All cultures were grown at $37^{\circ} \mathrm{C}$. Liquid cultures were incubated in an Environ-Shaker 3527 (Labline Instruments, Melrose Park, Ill., U.S.A.) set at $200 \mathrm{rev} . \mathrm{min}^{-1}$. Cell density was determined with a Klett-Summerson colorimeter (Klett Manufacturing Co., New York, U.S.A.) model 900-3 equipped with a no. 54 filter. Klett units were converted to cell numbers or absorbance units by reference to a standard curve. Cell density was also determined by absorbance at $660 \mathrm{~nm}$ using a Beckman model 25 spectrophotometer (Beckman Instruments, Fullerton, Calif., U.S.A.).

Preparation of cell extracts. Cultures were grown to a cell density of approximately $5 \times 10^{8} \mathrm{ml}^{-1}$ and 


\section{Table 1. Origin and characteristics of the Salmonella typhimurium strains used}

\begin{tabular}{|c|c|c|}
\hline Strain & Phenotype & Source \\
\hline LT2 (S1) & Wild-type & P. E. Hartman \\
\hline LT2 (S121) & Wild-type & B. N. Ames \\
\hline pyrA35 & $\mathrm{Pyr}^{-} \mathrm{Arg}^{-}$ & \\
\hline pyr $A 78$ & $\mathrm{Pyr}^{-} \mathrm{Arg}^{-}$ & \\
\hline pyrA81 & $\mathrm{Pyr}^{-} \mathrm{Arg}^{-}$ & \\
\hline pyrA102 & $\mathrm{Pyr}^{-} \mathrm{Arg}^{-}$ & \\
\hline pyrB118 & $\mathrm{Pyr}^{-}$ & \\
\hline pyrC138 & Pyr - & K. E. Sanderson \\
\hline pyrD13 & Pyr $^{-}$ & \\
\hline pyrD24 & Pyr $^{-}$ & \\
\hline pyrD135 & $\mathrm{Pyr}^{-}$ & \\
\hline pyrD95 & Pyr $^{-}$ & \\
\hline pyrE125 & $\mathrm{Pyr}^{-}$ & \\
\hline pyrF146 & Pyr $^{-}$ & \\
\hline
\end{tabular}

harvested by centrifugation at $10000 \mathrm{~g}$ for $5 \mathrm{~min}$. The cell pellet was resuspended to one-half of the original volume in ice-cold $40 \mathrm{~mm}$-potassium phosphate buffer, $\mathrm{pH} 7 \cdot 0$, and recentrifuged. The resulting cell pellet was then resuspended in sufficient ice-cold $40 \mathrm{~mm}$-potassium phosphate buffer, $\mathrm{pH} 7 \cdot 0$, to give about $10^{10}$ cells $\mathrm{ml}^{-1}$. The cells were disrupted by treatment with a Heat Systems model SW185 sonic oscillator (Plainview, N.Y., U.S.A.) at a setting of 40 for a total of $50 \mathrm{~s}(5 \times 10 \mathrm{~s}$ bursts with a $30 \mathrm{~s}$ cooling period between each burst). The extract was centrifuged at $10000 \mathrm{~g}$ for $5 \mathrm{~min}$ at $4{ }^{\circ} \mathrm{C}$, and $0.5 \mathrm{ml}$ of the supernatant was withdrawn for the assay of dihydroorotate dehydrogenase. The remaining extract was centrifuged at $27000 \mathrm{~g}$ for $30 \mathrm{~min}$ at $4{ }^{\circ} \mathrm{C}$, and the supernatant was removed and, in general, used for enzyme assays without further treatment.

Enzyme assays. All assays were carried out at $30^{\circ} \mathrm{C}$. Changes in absorbance were measured with a Beckman model 25 recording spectrophotometer. Specific activities of the enzymes were determined under conditions in which product formation (or substrate utilization) was proportional to the amount of extract and time

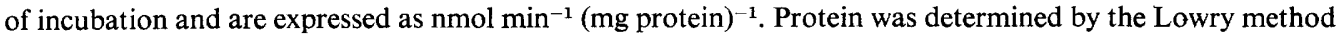
using bovine serum albumin as standard.

Aspartate carbamoyltransferase (EC 2.1.3.2; carbamoylphosphate:L-aspartate carbamoyltransferase). The method of Gerhart \& Pardee (1962) was used with modifications. The reaction mixture contained the following in $1 \mathrm{ml}: 4 \mu \mathrm{mol}$ dilithium carbamoylphosphate; $5 \mu \mathrm{mol} \mathrm{L}$-aspartate; $40 \mu \mathrm{mol}$ potassium phosphate

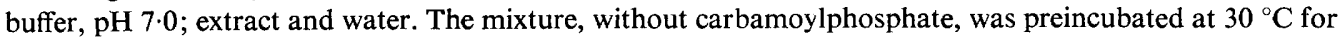
2 min and the reaction was started by the addition of carbamoylphosphate, freshly prepared and kept on ice before use. At 10,20 and 30 min intervals, $0.5 \mathrm{ml}$ samples were withdrawn and added to $0.5 \mathrm{ml}$ water. One $\mathrm{ml}$ of the colour mix of Prescott \& Jones (1969) was added immediately to the sample tube to stop the reaction and for later colour development. After vigorous mixing, the sample tube was placed in ice-water until all the samples had been taken.

Dihydroorotase (EC 3.5.2.3; L-5,6-dihydroorotate amidohydrolase). The assay mixture contained the following in $1 \mathrm{ml}: 1 \mu \mathrm{mol}$ dihydroorotate; $1 \mu \mathrm{mol}$ EDTA; $100 \mu \mathrm{mol}$ Tris $/ \mathrm{HCl}$ buffer, $\mathrm{pH} 8 \cdot 6$; extract and water. At 3,6 and 9 min intervals, $0.5 \mathrm{ml}$ samples of the assay mixture were withdrawn and treated in the same way as the aspartate carbamoyltransferase assay samples.

Ornithine carbamoyltransferase (EC 2.1.3.3; carbamoylphosphate:L-ornithine carbamoyltransferase). The assay mixture contained the following in $1 \mathrm{ml}: 10 \mu \mathrm{mol} \mathrm{L}$-ornithine; $4 \mu \mathrm{mol}$ dilithium carbamoylphosphate; $100 \mu \mathrm{mol}$ Tris/ $\mathrm{HCl}$ buffer, $\mathrm{pH} 8.6$; extract and water. The mixture was preincubated for $2 \mathrm{~min}$ at $30^{\circ} \mathrm{C}$ before carbamoylphosphate was added to start the reaction. Samples of $0.5 \mathrm{ml}$ were withdrawn at 3,6 and 9 min intervals and colour was developed as before.

In the above three enzyme assays, the formation of ureido groups was measured by the method of Prescott \& Jones (1969). These three enzyme assays were done at the same time. Sample tubes for the three assays were read at $466 \mathrm{~nm}$ against an appropriate water blank. The sample points obtained for each enzyme extract were plotted as absorbance versus time. The slopes of such linear plots gave the change in absorbance $\min ^{-1}$; thus, in conjunction with the experimentally determined absorption coefficient and the protein determination, specific activities were calculated.

Dihydroorotate dehydrogenase (EC 1.3.3.1; L-5,6-dihydroorotate: oxygen oxidoreductase). The extract from the low-speed centrifugation was used because dihydroorotate dehydrogenase is membrane-bound in E. coli and S. typhimurium. The spectrophotometric assay of Beckwith et al. (1962) was used with slight 
Table 2. Repressed and derepressed activities of five pyrimidine enzymes and one arginine enzyme from two wild-type strains of S. typhimurium

Strains were grown in glucose minimal medium with uracil $\left(50 \mu \mathrm{g} \mathrm{ml}^{-1}\right.$; repressed enzyme activity) or without uracil (derepressed activity). The extent of derepression (fold-derepression) was calculated by dividing the derepressed specific activity by the repressed specific activity. Specific activities were expressed as nmol $\mathrm{min}^{-1}$ (mg protein) ${ }^{-1}$.

\begin{tabular}{|c|c|c|c|c|c|c|}
\hline & \multicolumn{3}{|c|}{ Strain S1 (Hartman) } & \multicolumn{3}{|c|}{ Strain S121 (Ames) } \\
\hline & Specific & activity & & Specific & activity & \\
\hline Enzyme & $\begin{array}{c}\text { De- } \\
\text { repressed }\end{array}$ & Repressed & $\begin{array}{l}\text { de- } \\
\text { repression }\end{array}$ & $\begin{array}{c}\text { De- } \\
\text { repressed }\end{array}$ & Repressed & $\begin{array}{l}\text { de- } \\
\text { repression }\end{array}$ \\
\hline moyltransferase & 13 & 4 & $3 \cdot 2$ & 13 & 4 & $3 \cdot 2$ \\
\hline & 96 & 92 & $1 \cdot 0$ & 90 & 87 & 1.0 \\
\hline dehydrogenase & 11 & 8 & $1 \cdot 3$ & 11 & 10 & $1 \cdot 1$ \\
\hline ribosyltransferase & 34 & 21 & $1 \cdot 6$ & 34 & 21 & $1 \cdot 6$ \\
\hline lase & 23 & 22 & $1 \cdot 1$ & 22 & 20 & $1 \cdot 1$ \\
\hline amoyltransferase & 119 & 178 & $0 \cdot 7$ & 112 & 145 & 0.8 \\
\hline
\end{tabular}

modification. The assay mixture contained the following in $1 \mathrm{ml}: 100 \mu \mathrm{mol}$ Tris $/ \mathrm{HCl}$ buffer, $\mathrm{pH} 8.6 ; 1 \mu \mathrm{mol}$ L-dihydroorotate; extract and water. The mixture was preincubated at $30{ }^{\circ} \mathrm{C}$ for $2 \mathrm{~min}$ before dihydroorotate was added to start the reaction. The increase in absorbance at $290 \mathrm{~nm}$ was followed using a molar absorption coefficient of $6.0 \times 10^{3} 1 \mathrm{~mol}^{-1} \mathrm{~cm}^{-1}$.

Orotate phosphoribosyltransferase (EC 2.4.2.10; orotidine-5'-phosphate:pyrophosphate phosphoribosyltransferase). The orotate phosphoribosyltransferase assay was also performed spectrophotometrically, using a slight modification of the original method of Fyfe et al. (1973). The assay mixture contained the following in $1 \mathrm{ml}: 100 \mu \mathrm{mol}$ Tris/HCl buffer, $\mathrm{pH} 8.6 ; 6 \mu \mathrm{mol} \mathrm{MgCl}_{2} ; 0.25 \mu \mathrm{mol}$ orotate; $0.6 \mu \mathrm{mol} 5$-phosphoribosyl-1-pyrophosphate (PRPP); extract and water. The mixture was preincubated for $2 \mathrm{~min}$ at $30^{\circ} \mathrm{C}$ before PRPP was added to start the reaction. The decrease in absorbance at $295 \mathrm{~nm}$ was followed using a molar absorption coefficient of $3.95 \times 10^{3} 1 \mathrm{~mol}^{-1} \mathrm{~cm}^{-1}$ (Fyfe et al., 1973).

Orotidine-5'-monophosphate (OMP) decarboxylase (EC 4.1.1.23; orotidine-5'-phosphate carboxy-lyase). The method of Beckwith et al. (1962) was used with appropriate modifications. Each reaction tube contained the following in $1 \mathrm{ml}: 100 \mu \mathrm{mol}$ Tris/HCl buffer, $\mathrm{pH} 8.6 ; 0.2 \mu \mathrm{mol}$ OMP; extract and water. The mixture was preincubated at $30^{\circ} \mathrm{C}$ for $2 \mathrm{~min}$ before OMP was added to start the reaction. The decrease in absorbance at $285 \mathrm{~nm}$ was followed using a molar absorption coefficient of $1.65 \times 10^{3} 1 \mathrm{~mol}^{-1} \mathrm{~cm}^{-1}(\mathrm{Fyfe}$ et al., 1973).

Chemicals. Carbamoylphosphate (dilithium), orotidine-5'-monophosphate, uracil, dihydroorotate, orotate, dithiothreitol, antipyrine, monoxime, ornithine, carbamoylaspartate, and 5-phosphoribosyl-1-pyrophosphate were obtained from Sigma. Other chemicals were reagent grade.

\section{RESULTS}

\section{Activities of pyrimidine enzymes in two wild-type strains of Salmonella typhimurium}

It was necessary to determine the normal activities of the pyrimidine enzymes in wild-type strains under our experimental conditions in order to make valid comparisons and conclusions. One wild-type strain (designated S1 in our laboratory collection) was supplied by Dr P. E. Hartman, while another (S121 in our collection) was from Dr B. N. Ames. Though several differences are known for the two strains (R. T. Vitopal, personal communication), we found no differences in their pyrimidine enzymes (Table 2). We chose strain S1 for all subsequent studies (this strain is available from Dr K. E. Sanderson as $S$. typhimurium LT2).

\section{Enzyme activity during batch culture}

Variations in the specific activities of some enzymes occurred during batch culture (Fig. 2). Aspartate carbamoyltransferase, dihydroorotase and ornithine carbamoyltransferase remained virtually constant during the growth phase, with activity decreasing when the 


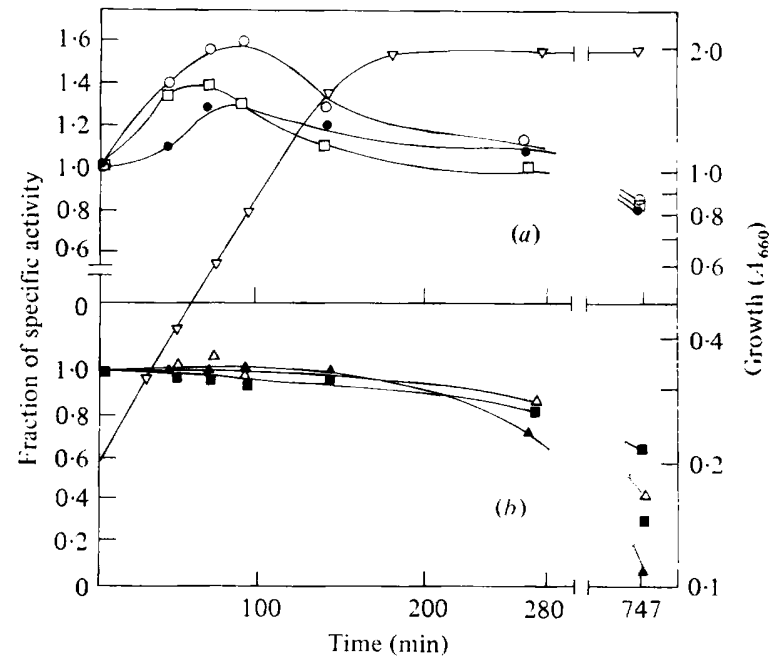

Fig. 2. Effect of growth phase on the specific activity of five pyrimidine enzymes and one arginine enzyme in $S$. typhimurium wild-type. The enzymes are: $\bigcirc$, dihydroorotate dehydrogenase; $\bigcirc, O M P$ decarboxylase; $\square$, orotate phosphoribosyltransferase; $\square$, aspartate carbamoyltransferase; $\triangle$, ornithine carbamoyltransferase; $\boldsymbol{\Delta}$, dihydroorotase. Growth curve $\left(A_{660}\right)$ of wild-type $S$. typhimurium in glucose minimal medium, $\nabla$. The generation time was $50 \mathrm{~min}$.

stationary phase was reached. Dihydroorotase showed the greatest loss of activity after growth had ceased (Fig. $2 b$ ). In contrast, the specific activities of the last three enzymes in the pyrimidine pathway to UMP did not remain constant throughout the growth cycle. Indeed, all three enzymes, the gene products of $p y r D, p y r E$ and $p y r F$, showed a peak of activity during the mid-exponential phase of growth (Fig. $2 a$ ). In addition, these enzymes - dihydroorotate dehydrogenase, orotate phosphoribosyltransferase and OMP decarboxylase - showed the least loss of activity after the cells entered the stationary phase.

It was therefore possible to choose an experimental range in which enzyme activity was constant or was at a peak. The experimental point chosen was maintained throughout each series of experiments performed in this study. All cells were harvested at the same turbidity and our derepression-level experiments were done as close as possible to this selected point.

\section{Derepressed activities of various Pyr- mutants}

Six enzymes were assayed in this series of experiments: aspartate carbamoyltransferase, dihydroorotase, dihydroorotate dehydrogenase, orotate phosphoribosyltransferase and OMP decarboxylase of the pyrimidine biosynthetic pathway, and ornithine carbamoyltransferase - the sister enzyme of aspartate carbamoyltransferase - of the arginine pathway (Fig. 1). Ornithine carbamoyltransferase was chosen as a control enzyme. We measured the activities of each enzyme using known deletion mutants for each of the pyrimidine enzymes (Table 1). Deletion mutants were used because they eliminated the possibility of any revertants to the wild-type. They also made possible the study of derepression levels without the consideration of protein-protein interactions between effectors and enzymes.

The various strains were inoculated into Klett flasks containing glucose minimal medium with $10 \mu \mathrm{g}$ uracil ml ${ }^{-1}$ and sufficient arginine $\left(50 \mu \mathrm{g} \mathrm{ml}^{-1}\right)$ for growth of pyr $A$ strains and for repression of the arginine enzymes, particularly ornithine carbamoyltransferase in our case. Thus, each strain could grow to approximately 100 observed Klett units before growth ceased because of pyrimidine limitation, and derepression of the pyrimidine enzymes began. We harvested the cells $90 \mathrm{~min}$ after growth ceased, thereby allowing ample time for maximum derepression to occur. The strains were also grown in the presence of repressive levels of uracil $\left(50 \mu \mathrm{g} \mathrm{ml}^{-1}\right)$ and arginine $\left(50 \mu \mathrm{g} \mathrm{ml}^{-1}\right)$ and harvested at 100 observed Klett units 
Table 3. Derepressed and repressed activities of five pyrimidine enzymes and one arginine enzyme from six deletion mutants of $S$. typhimurium

Strains were grown in glucose minimal medium plus arginine $\left(50 \mu \mathrm{g} \mathrm{ml}^{-1}\right)$ in uracil-sufficient (50 $\mu \mathrm{g} \mathrm{ml}^{-1}$; repressed enzyme activity) and uracil-limiting $\left(10 \mu \mathrm{g} \mathrm{ml}^{-1}\right.$; derepressed activity) conditions. Derepression was allowed to proceed for $90 \mathrm{~min}$ after growth ceased due to limiting uracil. The extent of derepression (fold-derepression) was calculated by dividing the derepressed specific activity by the repressed specific activity. Specific activities were expressed as nmol $\mathrm{min}^{-1}$ (mg protein $)^{-1}$.

Strains were also grown in glucose minimal medium without arginine, with or without uracil, and enzyme assays were carried out as above. However, except for ornithine carbamoyltransferase, the results obtained were very similar to those shown below. The results for ornithine carbamoyltransferase are shown in parentheses.

\begin{tabular}{|c|c|c|c|c|c|c|c|c|c|}
\hline \multirow[b]{3}{*}{ Strain } & \multicolumn{3}{|c|}{$\begin{array}{c}\text { Aspartate } \\
\text { carbamoyltransferase }\end{array}$} & \multicolumn{3}{|c|}{ Dihydroorotase } & \multicolumn{3}{|c|}{$\begin{array}{l}\text { Dihydroorotate } \\
\text { dehydrogenase }\end{array}$} \\
\hline & \multicolumn{2}{|c|}{ Specific activity } & \multirow{2}{*}{$\begin{array}{c}\text { Fold- } \\
\text { dere- } \\
\text { pression }\end{array}$} & \multicolumn{2}{|c|}{ Specific activity } & \multirow{2}{*}{$\begin{array}{c}\text { Fold- } \\
\text { dere- } \\
\text { pression }\end{array}$} & \multicolumn{2}{|c|}{ Specific activity } & \multirow{2}{*}{$\begin{array}{c}\text { Fold- } \\
\text { dere- } \\
\text { pression }\end{array}$} \\
\hline & $\begin{array}{l}\text { Dere- } \\
\text { pressed }\end{array}$ & $\begin{array}{c}\text { Re- } \\
\text { pressed }\end{array}$ & & $\begin{array}{l}\text { Dere- } \\
\text { pressed }\end{array}$ & $\begin{array}{c}\text { Re- } \\
\text { pressed }\end{array}$ & & $\begin{array}{l}\text { Dere- } \\
\text { pressed }\end{array}$ & $\begin{array}{c}\text { Re- } \\
\text { pressed }\end{array}$ & \\
\hline pyrA81 & 128 & 5 & 26 & 111 & 77 & $1 \cdot 5$ & 20 & 6 & $3 \cdot 3$ \\
\hline pyrB118 & - & - & - & 95 & 72 & $1 \cdot 3$ & 13 & 7 & 1.9 \\
\hline pyrC138 & 101 & 5 & 20 & - & - & - & 12 & 7 & 1.8 \\
\hline pyrD135 & 80 & 5 & 16 & 191 & 67 & $2 \cdot 9$ & - & - & - \\
\hline pyrE125 & 76 & 5 & 15 & 192 & 62 & $3 \cdot 1$ & 11 & 6 & 1.9 \\
\hline \multirow[t]{4}{*}{ pyrF146 } & 60 & 5 & 14 & 192 & 62 & $3 \cdot 1$ & 9 & 7 & $1 \cdot 3$ \\
\hline & \multicolumn{3}{|c|}{$\begin{array}{c}\text { Orotate } \\
\text { phosphoribosyltransferase }\end{array}$} & \multicolumn{3}{|c|}{$\begin{array}{c}\text { OMP } \\
\text { decarboxylase }\end{array}$} & \multicolumn{3}{|c|}{$\begin{array}{c}\text { Ornithine } \\
\text { carbamoyltransferase }\end{array}$} \\
\hline & \multicolumn{2}{|c|}{ Specific activity } & \multirow{2}{*}{$\begin{array}{c}\text { Fold- } \\
\text { dere- } \\
\text { pression }\end{array}$} & \multicolumn{2}{|c|}{ Specific activity } & \multirow{2}{*}{$\begin{array}{l}\text { Fold- } \\
\text { dere- } \\
\text { pression }\end{array}$} & \multicolumn{2}{|c|}{ Specific activity } & \multirow{2}{*}{$\begin{array}{c}\text { Fold- } \\
\text { dere- } \\
\text { pression }\end{array}$} \\
\hline & $\begin{array}{c}\text { Dere- } \\
\text { pressed }\end{array}$ & $\underset{\text { pressed }}{\mathbf{R e}-}$ & & $\begin{array}{c}\text { Dere- } \\
\text { pressed }\end{array}$ & $\begin{array}{c}\mathbf{R e}- \\
\text { pressed }\end{array}$ & & $\begin{array}{c}\text { Dere- } \\
\text { pressed }\end{array}$ & $\underset{\text { pressed }}{\mathbf{R e}-}$ & \\
\hline pyr $A 81$ & 55 & 20 & $2 \cdot 8$ & 34 & 20 & $1 \cdot 7$ & 33 & 3 & $11 \cdot 0$ \\
\hline pyrB118 & 56 & 20 & $2 \cdot 8$ & 34 & 21 & $1 \cdot 6$ & $\begin{array}{c}7 \\
(111)\end{array}$ & $\begin{array}{c}6 \\
(113)\end{array}$ & $\begin{array}{c}1 \cdot 1 \\
(1 \cdot 0)\end{array}$ \\
\hline pyrC138 & 56 & 20 & $2 \cdot 8$ & 34 & 21 & $1 \cdot 6$ & $\begin{array}{c}7 \\
(162)\end{array}$ & $\begin{array}{c}7 \\
(140)\end{array}$ & $\begin{array}{c}1 \cdot 0 \\
(1 \cdot 2)\end{array}$ \\
\hline pyrD135 & 53 & 21 & $2 \cdot 6$ & 33 & 21 & $1 \cdot 6$ & $\begin{array}{c}39 \\
(140)\end{array}$ & $\begin{array}{c}3 \\
(112)\end{array}$ & $\begin{array}{l}13 \cdot 0 \\
(1 \cdot 2)\end{array}$ \\
\hline pyrE125 & - & - & - & 33 & 21 & $1 \cdot 6$ & $\begin{array}{c}4 \\
(187)\end{array}$ & $\begin{array}{c}4 \\
(174)\end{array}$ & $\begin{array}{c}1 \cdot 0 \\
(1 \cdot 1)\end{array}$ \\
\hline pyrF146 & 53 & 20 & $2 \cdot 7$ & - & - & - & $\begin{array}{c}5 \\
(181)\end{array}$ & $\begin{array}{c}5 \\
(173)\end{array}$ & $\begin{array}{l}1 \cdot 0 \\
(1 \cdot 1)\end{array}$ \\
\hline
\end{tabular}

to measure the repressed enzyme levels. The cells were then centrifuged, ultrasonically disrupted and assayed for the pyrimidine enzymes and ornithine carbamoyltransferase, all within the same day. Enzyme extracts were then frozen and the protein contents were measured later. Table 3 presents details of the specific activities of each of the six enzymes from the uracil-limited (derepressed) and uracil-sufficient (repressed) cells together with the extent of derepression (derepressed specific activity/repressed specific activity) obtained for each enzyme.

When this experiment was repeated with arginine omitted, only the results for ornithine carbamoyltransferase were different (Table 3). The higher specific activities found for this enzyme are due to derepression of the arginine enzymes in the absence of arginine.

Aspartate carbamoyltransferase was the most derepressed of any of the six enzymes 


\section{Table 4. Specific activity of ornithine carbamoyltransferase in randomly selected pyr $A$ and pyr $D$ mutants grown in arginine and limiting uracil}

Strains were grown in glucose minimal medium with arginine $\left(50 \mu \mathrm{g} \mathrm{ml}^{-1}\right)$ and limiting uracil $\left(10 \mu \mathrm{g} \mathrm{ml}^{-1}\right)$. The cells were starved for $90 \mathrm{~min}$ after growth ceased due to limiting uracil. Strains (and numbers) in parentheses gave the anomalous result described in the text and shown in Table 3.

$\begin{array}{cc}\text { Strain } & \begin{array}{c}\text { Specific activity } \\ \left.\text { [nmol } \text { min }^{-1}(\mathrm{mg} \text { protein })^{-1}\right]\end{array} \\ (\text { pyr } A 81) & (33) \\ \text { pyrA35 } & 11 \\ \text { pyrA78 } & 9 \\ \text { pyrA102 } & 5 \\ \text { pyrD13 } & 8 \\ \text { pyrD24 } & 8 \\ \text { pyrD95 } & 7 \\ \text { pyrD135) } & (39)\end{array}$

(Table 3). In addition, the extent of the derepression seemed to depend on the gene which harboured the mutation causing the pyrimidine requirement. A mutation early in the pyrimidine pathway, e.g. pyrA81, caused the greatest level of derepression (Table $3 ; 26$-fold) while a mutation in a late gene, $p y r F$, caused the least level of derepression (Table $3 ; 14-$ fold). Thus, a $p y r A$ deletion strain caused approximately twice the level of aspartate carbamoyltransferase derepression of a $p y r F$ deletion strain. For comparison, the extent of derepression (i.e. minimal-grown specific activity/uracil-grown specific activity) obtained for aspartate carbamoyltransferase in the wild-type was about 3-fold (Table 2).

Dihydroorotase was not as derepressible as aspartate carbamoyltransferase (Table 3 ). Unlike aspartate carbamoyltransferase, the maximum derepression obtained for dihydroorotase was a little over 3-fold and the greatest derepression was found when a strain that harboured a mutation in a late gene (e.g. $p y r F$ ) was limited for uracil.

The patterns of derepression seen for dihydroorotate dehydrogenase (Table 3) resembled those for aspartate carbamoyltransferase - the later the gene mutation the smaller the amount of derepression possible - but the extent of the derepression was only about 3-fold. A mutation in a late gene, pyrF146, gave only 1-3-fold derepression while a mutation in an early gene, pyr $A 81$, gave $3 \cdot 3$-fold derepression.

There appeared to be no change in the level of derepression for orotate phosphoribosyltransferase regardless of the mutant strain involved, and the enzyme activities remained constant, at about 2.7-fold derepression (Table 3 ).

OMP decarboxylase showed the least derepression (maximum 1.7-fold) of any of the enzymes of the pyrimidine pathway investigated, and its activity was constant regardless of the mutant strain employed (Table 3).

Ornithine carbamoyltransferase was chosen as a control enzyme to determine if the derepression observed was limited to the pyrimidine pathway, as we intended, or if it was a product of a more general derepression. Also, since ornithine carbamoyltransferase was involved in the pyrimidine pathway, and performed the same function as aspartate carbamoyltransferase (i.e. carbamoyl transfer), sharing the same unstable pool of carbamoylphosphate, but for arginine biosynthesis, it seemed that ascertaining the activities of this enzyme might be informative. We found that for two of the strains used, namely pyrA8I and pyrD135, ornithine carbamoyltransferase was derepressed to a significant extent when uracil was limiting even though sufficient arginine was available $\left(50 \mu \mathrm{g} \mathrm{ml}^{-1}\right)$ to cause normal repression. When pyrA81 and pyrD135 strains were grown with sufficient uracil $\left(50 \mu \mathrm{g} \mathrm{ml}^{-1}\right)$ and arginine and harvested at 100 observed Klett units (i.e. not limiting for pyrimidines), ornithine carbamoyltransferase was repressed to a level comparable with that of the other strains (Table 3). To determine if this derepression was of a general nature (i.e. true for all 


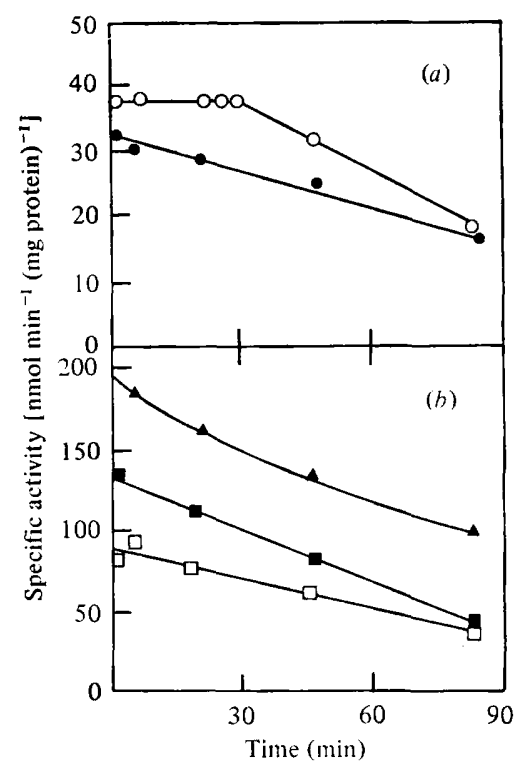

Fig. 3. Kinetics of repression for five pyrimidine enzymes. Fully derepressed cells were treated with exogenous uracil $\left(50 \mu \mathrm{g} \mathrm{ml}^{-1}\right)$ and the kinetics of repression were followed with growth. The enzymes are: $O$, dihydroorotate dehydrogenase; $O$, OMP decarboxylase; $\boldsymbol{\Delta}$, dihydroorotase; $\square$, aspartate carbamoyltransferase; $\square$ orotate phosphoribosyltransferase. The generation times of all cultures varied between 48 and $52 \mathrm{~min}$.

pyr $A$ and $\operatorname{pyr} D$ mutants), three further mutant strains of each gene were assayed under conditions where derepression was observed. Surprisingly, no significant derepression of ornithine carbamoyltransferase was found in the presence of arginine with limiting uracil for any of the six new mutant strains examined (Table 4).

\section{Kinetics of repression for the pyrimidine enzymes}

One final critical question remained, namely - what happens when exogenous uracil, known to cause repression, is offered to a strain with greatly derepressed enzyme levels? To answer this question, we chose the pyr $A 78$ strain because it showed comparable derepressed levels of the pyrimidine enzymes to the pyr $A 81$ strain without the unusual derepression of ornithine carbamoyltransferase in the presence of arginine and limiting uracil.

The pyrA78 strain was grown in glucose minimal medium with arginine $\left(50 \mu \mathrm{g} \mathrm{ml}^{-1}\right)$ and limiting uracil to 100 Klett units until growth ceased. After sufficient time had elapsed ( $90 \mathrm{~min})$ for derepression to be expressed, uracil $\left(50 \mu \mathrm{g} \mathrm{ml}^{-1}\right)$ was added to the culture medium. Samples were taken immediately and at intervals thereafter for assay of the pyrimidine enzymes. Since we knew the cell generation time and the pattern of repression obtained, it was possible to determine if enzyme turnover occurred or if the enzymes were diluted out with cell generations. If the activity of a particular enzyme decreased by approximately a factor of two (i.e. became $50 \%$ ) after a generation time then one could assume that the enzyme was present and that the observed decrease in activity was merely the result of dilution by cell division.

The activity of aspartate carbamoyltransferase decreased by a factor of two with each successive cell division time (Fig. $3 b$ ). Dihydroorotase showed repression kinetics nearly identical to aspartate carbamoyltransferase although the decrease in dihydroorotase activity was more gradual. Orotate phosphoribosyltransferase and OMP decarboxylase each gradually decreased in activity but the decrease was not linear with cell division. The activity of dihydroorotate dehydrogenase remained constant for $30 \mathrm{~min}$ before a decline was seen. 


\section{DISCUSSION}

We wish to make the following four points as a result of this study. (1) The activities of the pyrimidine biosynthetic enzymes were nearly identical in two different wild-type strains of S. typhimurium (Table 2). (2) The specific activity of the pyrimidine enzymes varied during the growth cycle of $S$. typhimurium and decreased rapidly when the stationary phase of growth was reached (Fig. 2). (3) Derepression was achieved by limiting $\mathrm{Pyr}^{-}$mutants for uracil. Maximum derepression, however, depended on the genotype of the $\mathrm{Pyr}^{-}$strain (Table 3). (4) When sufficient uracil was added to fully derepressed cells, enzyme activities decreased with each successive cell division. Thus, dilution by growth, and not enzyme turnover, explained the kinetics of repression (Fig. 3).

The determination of the pyrimidine enzyme activities in two wild-type strains under our experimental conditions allowed the establishment of standards of normality for the experiments described in this paper. The wild-type strains investigated, S1 and S121, compared well as to the extent of repression and derepression observed for the pyrimidine biosynthetic enzymes (Table 2). As an informational standard, wild-type $S$. typhimurium aspartate carbamoyltransferase is normally derepressed 3-fold when uracil is absent from the medium (i.e. in minimal medium).

Ornithine carbamoyltransferase, even though not an enzyme of the pyrimidine pathway, increased 1.4-fold when uracil was present in the medium. This can be explained as follows. Carbamoylphosphate synthetase, the first enzyme of the pyrimidine pathway (see Fig. 1), is subject to cumulative repression by arginine and a pyrimidine compound in $E$. coli (Pierard et al., 1965, 1976) and in S. typhimurium (Abdelal \& Ingraham, 1969, 1975). The addition of uracil caused partial repression of carbamoylphosphate synthetase which, in turn, decreased the concentration of carbamoylphosphate. It therefore seemed logical that the ornithine carbamoyltransferase activity increased to satisfy the demand for citrulline for the arginine pathway in the presence of uracil.

Since the two wild-type strains were comparable for the pyrimidine biosynthetic enzymes and ornithine carbamoyltransferase, derivatives of either strain could be used for further experiments.

Salmonella typhimurium LT2 (S1) was chosen as the wild-type and grown in minimal medium to determine the levels of enzyme activity (measured as specific activity) during the various phases of batch culture. Aspartate carbamoyltransferase activity remained virtually constant throughout the exponential phase of growth but started to decline as the culture entered the stationary phase (Fig. $2 b$ ). Thus, any experiments with aspartate carbamoyltransferase could best be carried out with cells harvested while actively growing in the exponential phase.

Dihydroorotase activity, like aspartate carbamoyltransferase, remained constant during the exponential phase of growth but differed from aspartate carbamoyltransferase in that there was a sharp decline in activity after the stationary phase was reached, which continued with time. It has been reported frequently for most organisms studied (Lacroute, 1968; Caroline, 1969; Caroline \& Davis, 1969; Fyfe et al., 1973) that dihydroorotase is a very unstable enzyme. However, in our study, the enzyme was quite stable provided that the cells were harvested at about 100 observed Klett units and that the enzyme was assayed promptly. Dihydroorotase lost activity rapidly once cells entered the stationary phase (Fig. 2b). Thus, it is imperative for all experiments with dihydroorotase to use cells harvested in the exponential phase of growth, with dihydroorotase assays being carried out on the day of harvest. We believe that this approach will do much to eliminate the instability previously attributed to dihydroorotase by ourselves (O'Donovan \& Neuhard, 1970) and others.

Whereas aspartate carbamoyltransferase and dihydroorotase remained constant during the growth cycle, this was not true for dihydroorotate dehydrogenase which showed a peak of activity corresponding to the mid-exponential phase of growth (Fig. $2 a$ ). The activity 
pattern of this enzyme showed that for maximum activity cells must be harvested not only during the exponential phase of growth but within a certain narrow range of cell concentrations. Dihydroorotate dehydrogenase appeared to be fairly stable after cessation of growth.

The last two enzymes of the pyrimidine pathway to UMP - orotate phosphoribosyltransferase and OMP decarboxylase - like dihydroorotate dehydrogenase, showed peaks of activity during the exponential phase of growth (Fig. $2 a$ ). Best results were obtained when harvesting of cells coincided with the peak-time.

Ornithine carbamoyltransferase activity paralleled aspartate carbamoyltransferase activity (Fig. $2 b$ ). The importance of this aspect of the study was an awareness of the need for consistency in all experimental procedures. Furthermore, these data allowed us to select a valid working point in the growth phase of each culture where enzyme activity was at its peak or remained constant. The mid-point of the exponential phase, at approximately 100 observed Klett units, appeared to provide the most suitable point for our experiments.

Maximum derepression of the pyrimidine enzymes and ornithine carbamoyltransferase was measured in deletion mutants for each of the pyrimidine enzymes. Aspartate carbamoyltransferase showed the greatest derepression (Table 3). The derepression was greater still when a mutant strain was used that lacked carbamoylphosphate synthetase, encoded by $p y r A$. Indeed, when a late pathway gene, $p y r F$, harboured the mutation, aspartate carbamoyltransferase was derepressed only 14-fold as opposed to 26-fold for an early pathway gene, pyrA. Thus, the earlier a mutation occurred in the genes encoding the pyrimidine enzymes, the greater was the derepression for aspartate carbamoyltransferase, when cells were starved for uracil. In other words, to get maximum derepression of aspartate carbamoyltransferase, one should limit pyrA strains in preference to other $\mathrm{Pyr}^{-}$mutants, especially pyrE and pyrF (Table 3 ). Arginine played no role in the derepression of aspartate carbamoyltransferase - the same level of derepression was seen in the presence or absence of arginine for all strains used.

In contrast to the pattern of derepression shown for aspartate carbamoyltransferase, the derepression found for dihydroorotase increased when a mutation in a late gene (e.g. pyrF) of the pyrimidine pathway was tested (Table 3). The limitation of a $p y r F$ strain for uracil elicited about twice as much derepression as the limitation of a $\operatorname{pyr} A$ strain. Arginine did not contribute to the derepression.

Dihydroorotate dehydrogenase exhibited the same pattern of derepression as aspartate carbamoyltransferase. Thus, the earlier the mutation occurred in the pyrimidine pathway, the greater was the dihydroorotate dehydrogenase activity (Table 3 ).

Orotate phosphoribosyltransferase represented a departure from any of the previously observed patterns of derepression in that the extent of derepression was the same regardless of the pyr gene mutated. Orotate phosphoribosyltransferase could be derepressed only about 3 -fold, i.e. about twice the level found for the wild-type. Arginine, once again, had no effect (Table 3):

OMP decarboxylase showed the least derepression of all the enzymes studied. The amount of derepression remained constant regardless of the $\mathrm{Pyr}^{-}$mutant examined. Indeed, the level of derepression was similar to that found for the wild-type strains (Table 2) and, once again, arginine had no effect on derepression.

Ornithine carbamoyltransferase was used as a control and also to see if the repression or derepression observed was specific for the pyrimidine pathway and not just a non-specific phenomenon. Nevertheless, in two strains, pyrA81 and pyrD135, ornithine carbamoyltransferase was derepressed 11- and 13-fold, respectively, even in the presence of sufficient arginine for repression $\left(50 \mu \mathrm{g} \mathrm{ml}^{-1}\right)$ whenever the cells were limited for uracil. This finding was unexpected, and it raised the question of whether this derepression was of a general nature, strain-specific (i.e. characteristic of pyrA81 and pyrD135 only) or characteristic of all pyrA and pyrD mutants.

A comparison of ornithine carbamoyltransferase activities within the group of six mutants 
used in this study in the presence of arginine and limiting uracil showed that these results were not of a general nature. Indeed, the other four strains we examined ( $p y r B 118$, pyrC138, pyrE125, pyrF146; Table 3) showed repressed levels of ornithine carbamoyltransferase under conditions of arginine supplementation and uracil limitation.

To determine if the results were strain-specific or were characteristic of all pyrA and pyr $D$ mutants, three $p y r A$ and three $p y r D$ strains, selected randomly from our laboratory collection, were assayed for ornithine carbamoyltransferase activity in the presence of arginine $\left(50 \mu \mathrm{g} \mathrm{ml}^{-1}\right)$ and limiting uracil. As can be seen from Table 4, the phenomenon appears to be allele-specific even though we provide no data to eliminate the background effects of the strains. All other pyrA and pyrD mutants examined showed repressed levels of ornithine carbamoyltransferase when grown in arginine and limited for uracil. Thus, neither pyr $A 81$ nor pyrD135 should be used in experiments involving arginine biosynthesis in $S$. typhimurium.

There appeared to be no constant overall pattern or level of derepression for the pyrimidine enzymes when different mutant strains were limited for uracil. Aspartate carbamoyltransferase and dihydroorotate dehydrogenase gave lower levels of derepression if a mutant with a block late in the pathway (e.g. $p y r F$ ) was starved for pyrimidines. Dihydroorotase, by contrast, gave the greatest derepression when a late gene mutation, such as $p y r F$, was used for pyrimidine limitation. And there was no difference in derepression levels for orotate phosphoribosyltransferase and OMP decarboxylase regardless of where the mutation was located.

There have been numerous reports that the final four enzymes in the pyrimidine pathway - encoded by $\operatorname{pyr} C$, pyr $D, p y r E$ and $p y r F$ - are coordinately repressed and derepressed (Beckwith et al., 1962; O'Donovan \& Neuhard, 1970) as opposed to when all the genes of a pathway are coordinately repressed and derepressed (Ames \& Garry, 1959; Ames et al., 1960). However, in our study, neither the levels of derepression nor their patterns appeared to be coordinate for the final four enzymes of the biosynthetic pathway to UMP. Orotate phosphoribosyltransferase and OMP decarboxylase showed the same pattern of derepression but did not show the same extent of derepression, while dihydroorotase and dihydroorotate dehydrogenase showed opposite patterns of derepression.

In fully derepressed bacteria, the kinetics of repression could be studied by adding exogenous uracil and following the decrease in the activities of the pyrimidine enzymes. Knowing the rate of repression and the cell generation time, it was possible to determine if enzyme turnover or dilution by cell division was responsible for the decreased activity observed. The same pattern of decrease was noted for all enzymes, except dihydroorotate dehydrogenase where the enzyme activity remained constant for one cell division before a decline was noted (Fig. 3). Aspartate carbamoyltransferase showed a decrease in activity compatible with cell division diluting out the enzyme by decreasing the enzyme activity to $50 \%$. The decline in dihydroorotase specific activity was nearly identical to that of aspartate carbamoyltransferase, decreasing at approximately $50 \%$ per generation. Dihydroorotate dehydrogenase differed from the other enzymes in that its activity appeared to remain constant before beginning to decline. One possibility that might account for this behaviour is that dihydroorotate dehydrogenase is membrane-associated (Taylor \& Taylor, 1964). The specific activities of orotate phosphoribosyltransferase and OMP decarboxylase reached $50 \%$ in approximately $90 \mathrm{~min}$, which is nearly twice the generation time, and so these two enzymes decreased at a slower rate than aspartate carbamoyltransferase.

Thus, except for the kinetics of repression seen for dihydroorotate dehydrogenase, the results were compatible with the idea of dilution by cell division. This is quite reasonable and physiologically economical. 
This work was supported by an International Collaborative grant from the North Atlantic Treaty Organisation to Gerard A. O'Donovan and by the Texas Agricultural Experiment Station Project No. 1670.

\section{REFERENCES}

AbDelal, A. \& Ingraham, J. L. (1969). Control of carbamyl phosphate synthesis in Salmonella typhimurium. Journal of Biological Chemistry 244, 4033-4038.

Abdelal, A. \& Ingraham, J. L. (1975). Carbamylphosphate synthetase from Salmonella typhimurium. Regulation, subunit composition and function of the subunits. Journal of Biological Chemistry 250, 4410-4417.

AMES, B. N. \& GARRY, B. (1959). Coordinate repression of the synthesis of four histidine biosynthetic enzymes by histidine. Proceedings of the National Academy of Sciences of the United States of America 45, 1453-1461.

Ames, B. N., Garry, B. J. \& Herzenberg, L. A. (1960). The genetic control of the enzymes of histidine biosynthesis in Salmonella typhimurium. Journal of General Microbiology 22, 369-378.

Beckwith, J. R., Pardee, A. B., Austrian, R. \& $\mathrm{J}_{\mathrm{ACOB}}$, F. (1962). Coordination of the synthesis of the enzymes in the pyrimidine pathway of Escherichia coli. Journal of Molecular Biology 5, 618-634.

Bellino, F. (1973). Continuous synthesis of partially derepressed aspartate transcarbamylase during the division cycle of Escherichia coli B/r. Journal of Molecular Biology 74, 223-238.

Caroline, D. F. (1969). Pyrimidine synthesis in Neurospora crassa: gene-enzyme relationships. Journal of Bacteriology 100, 1371-1377.

Caroline, D. F. \& Davis, R. H. (1969). Pyrimidine synthesis in Neurospora crassa: regulation of enzyme activities. Journal of Bacteriology 100, 1378-1384.

Fyfe, J. A., Miller, R. L. \& Krenitsky, T. A. (1973). Kinetical properties and inhibition of orotidine-5'-phosphate decarboxylase. Journal of Biological Chemistry 248, 3801-3809.

Gerhart, J. C. \& Pardee, A. B. (1962). The enzymology of control by feedback inhibition. Journal of Biological Chemistry 237, 891-896.

LACROUTE, F. (1968). Regulation of pyrimidine biosynthesis in Saccharomyces cerevisiae. Journal of Bacteriology 95, 824-832.

Munch-Petersen, A. \& Neuhard, J. (1964). Studies on the acid-soluble nucleotide pool in thymine-requiring mutants of Escherichia coli during thymine starvation. Biochimica et biophysica acta 80, 542-551.

O'Donovan, G. A. \& Neuhard, J. (1970). Pyrimidine metabclism in microorganisms. Bacteriological Reviews 34, 278-343.

Pierard, A., Glansdorff, N., Mergeay, M. \& WIAME, J. M. (1965). Control of biosynthesis of carbamyl phosphate in Escherichic coli. Journal of Molecular Biology 14, 23-36.

Pierard, A., Glansdorff, N., Gigot, D., Crabeel, M., HalleuX, P. \& Thiry, L. (1976). Repression of Escherichia coli carbamoylphosphate synthase: relationships with enzyme synthesis in the arginine and pyrimidine pathways. Journal of Bacteriology 127, 291-301.

Prescott, L. M. \& Jones, M. E. (1969). Modified methods for the determination of carbamyl aspartate. Analytical Biochemistry 32, 408-419.

TAYLOR, W. H. \& TAYLOR, M. L. (1964). Enzymes of the pyrimidine pathway of Escherichia coli. II. Intracellular localization and properties of dihydroorotic dehydrogenase. Journal of Bacterio$\log y$ 88, 105-110. 